\title{
Overexpression of c-Met and of the transducers PI3K, FAK and JAK in breast carcinomas correlates with shorter survival and neoangiogenesis
}

\author{
STÉPHANE GARCIA ${ }^{1}$, JEAN-PHILIPPE DALES ${ }^{1}$, EMMANUELLE CHARAFE-JAUFFRET ${ }^{2}$, \\ SÉVERINE CARPENTIER-MEUNIER ${ }^{1}$, LUCILE ANDRAC-MEYER ${ }^{1}$, JOCELYNE JACQUEMIER ${ }^{2}$, \\ CLAUDINE ANDONIAN $^{1}$, MARIE-NÖ̈LLE LAVAUT ${ }^{1}$, CLAUDE ALLASIA ${ }^{3}$, \\ PASCAL BONNIER $^{4}$ and COLETTE CHARPIN ${ }^{1}$ \\ ${ }^{1}$ Department of Pathology, Centre Hospitalo-Universitaire, Hôpital Nord; ${ }^{2}$ Department of Biopathology, Institut \\ Paoli Calmettes; ${ }^{3}$ Faculté de Médecine Timone; ${ }^{4}$ Departments of Gynecology and Breast Oncology, \\ Hôpital de la Conception, AP-HM/Centre Hospitalier Privé Beauregard, Marseille, France
}

Received November 30, 2006; Accepted January 25, 2007

\begin{abstract}
Met is responsible for cell motility and tumour spreading. c-Met expression and signal transducers reflecting c-Met functionality were investigated in breast carcinomas, in correlation with patient outcome and tumour vasculature. Tissue microarrays of 930 breast carcinomas were constructed, categorised according to patients' follow-up (4- to 10-year follow-up; median, 6.5 years). Standardised immunocytochemical procedures were performed using anti-c-Met, -PI3K, -FAK, -JAK, and -CD146, -FYN and an automated autostainer (Ventana). High-throughput densitometry measuring the extent of immunoprecipitates was assessed by image analysis (SAMBA). c-Met overexpression correlated with poor survival along with PI3K and FAK reflecting c-Met functionality and CD146 and FYN expression in endothelial cells. Automated quantification of immunocytochemical precipitates using image analysis was shown to provide an objective means of measuring cellular proteins that are potentially relevant for current practice in pathological diagnosis and for specific therapy combining inhibitors of both c-Met and downstream transducer pathways, and of tumour angiogenesis.
\end{abstract}

\section{Introduction}

The action of inhibitors of tyrosine kinase receptors (such as trastuzumab, imatinib, bevacizumab and gefitinib) illustrates the value of targeting this protein class for treatment of selected

Correspondence to: Professor Colette Charpin-Taranger, Faculté Nord, Service d'Anatomie et de Cytologie Pathologiques, Boulevard Pierre Dramard, 13916 Marseille Cedex 20, France

E-mail: colette.charpin@ap-hm.fr

Key words: tissue microarray, densitometry, c-Met, signal transducers cancers. As a member of the receptor tyrosine kinase (RTK) family, c-Met also represents a target for cancer therapy. c-Met is a high-affinity receptor for hepatocyte growth factor (HGF) or scatter factor (SF) and is significantly overexpressed within tumour cells. c-Met and HGF are required for normal mammalian development and play an important role in epithelial mesenchymal interactions during organ morphogenesis $(1,2)$. c-Met is expressed in most carcinomas, and elevated expression relative to normal tissue has been detected in a number of carcinomas including lung, breast, colorectal, prostate, pancreatic, head and neck, gastric, hepatocellular, ovarian and renal carcinomas and in gliomas, melanomas and some sarcomas (3-6). c-Met expression is regulated in tumours by a number of epigenetic mechanisms involving tumoursecreted growth factors, tumour hypoxia and activation of other oncogenes (7-9). In addition, c-met amplification and subsequent overexpression have been reported in gastric and colorectal cancers and gliomas (10-12). c-Met and HGF overexpression enhances the growth of neoplasms and invasion. The diverse set of cellular functions regulated by this receptor influences some obligatory steps during the metastatic process including: i) migration, secretion of proteolytic enzymes and invasive growth of tumour cells during extravasation; ii) anoikis, or survival of tumour cells in vasculature; iii) arrest in capillary beds and invasive extravasation of tumour cells to form micrometastases; and finally iv) cell growth and survival at diverse remote microenvironments supporting the growth of metastasis. In addition, the increased production of HGF by tumoural stromal cells in neoplasms at both primary and metastatic sites may affect the recruitment of endothelial cells and formation of microcapillaries during tumour neovascularisation. In support of this role, the endothelial expression of c-Met and stimulation of endothelial growth, invasion and motility by HGF have been demonstrated in vitro (9), resulting in neovascularisation $(13,14)$. HGF has also been demonstrated to upregulate the expression of pro-angiogenic factors including VEGF, IP8 and UPA by both tumour cells and vascular smooth muscle cells, and to downregulate expression 
of antiangiogenic factors such as thrombospondin-1. In addition, it increases expression of VEGF-R2 by endothelial cells $(9,13,14)$.

At the molecular level, binding of activated HGF to the c-Met extracellular ligand-binding domain results in receptor multimerisation and phosphorylation of multiple tyrosine residues at intracellular regions, that regulate internalization, catalytic activities and docking of regulatory substrates. Activation of c-Met results in binding phosphorylation in adaptor proteins (mainly Gab 1 and to a lesser extent Gab 2), with subsequent activation of signal transducers such as PI3K, FAK, JUN (amino-terminal kinase JNK), ERK and STATs, also regulated through JAK, another signal transducer activated by the transmembrane non-tyrosine kinase cytokine IL-6 receptor $(4,6,13,14)$. Although other RTKs signal through these pathways, c-Met differs in the following: i) the presence of the unique multisubstrate docking site at the c-terminal region of the receptor; and ii) signalling through the specific adaptor proteins Gab 1 and 2. Another particular feature of c-Met signalling is its interaction with focal adhesion complexes and non-kinase binding partners such as $\$ 4$ integrin, CD44, semaphorin and ezrin $(3,5,13)$. Downstream of Gab 1 , the regulation of cell motility, cell dissociation, cell adhesion and invasion by c-Met has been shown to be dependent on both PI3K and ERK pathways. PI3K has been shown to control c-Met-dependent cell survival. FAK also acts on cell motility and invasion through the loss of tight junctions and facilitation of adhesion of tumour cells onto the extracellular matrix. JAK and STATs participate in branching morphogenesis $(3,4,13)$.

In the present study, we used immunohistochemistry to document variation in c-Met expression in a large series $(n=930)$ of breast carcinomas, as well as expression of the c-Met signal transducers PI3K and FAK. Our objective was to correlate expression of these proteins in tumour cells with patient outcome, in order to identify potential intratumoural targets for specific inhibitors with potential relevance for cancer therapy $(3-6,13,14)$. We used a standardised method to identify overexpression of these proteins in tumours, and a new high-throughput method of evaluation including tissue microarray (TMA) and quantitative densitometry after automated digitisation of microscopic images of immunostaining.

In previous studies (15-17), we showed that angiogenic factors such as CD105, Tie2, VEGFR2, HIF and CD31 in frozen samples are valid objective indicators of tumour neoangiogenesis that correlate with poor survival and high metastatic risk. However, we found that TMA was not suitable for evaluation of angiogenesis due to the small diameter $(0.6 \mathrm{~mm})$ of cores from which paraffin sections were assessed (18). Subsequently, we more successfully examined CD146/ Mel-CAM labelling of activated endothelial cells in TMA (unpublished data). Since remote metastases develop through blood vessels, we also aimed to evaluate CD146 expression as a reflection of tumour vasculature, using the same technical approach, in correlation with c-Met expression.

Various inhibitors suitable for antiangiogenic therapy have been reported (reviewed in ref. 19). However, the preliminary results of clinical studies have suggested that antiangiogenic therapy has poor activity in advanced tumours, but some controversial trials have claimed significantly better outcome when an antivascular endothelial growth factor antibody was combined with chemotherapy as front-line therapy against colorectal cancer, a finding that has renewed interest in this therapeutic strategy (19). Also, it has been shown that proinvasive effects of hypoxia activate transcription of the c-met proto-oncogene, resulting in higher levels of c-Met, thus amplifying HGF signalling. Inhibition of c-Met expression prevents hypoxia-induced invasive growth (9). Neoplastic cells escape hypoxia by invading surrounding tissues where oxygen and nutrients are available. This invasive switch that links tumour hypoxia to increased malignancy points to the therapeutic relevance of suppressing cell motility when targeting tumour vasculature in order to prevent the potential spread of cancer cells following intratumoural oxygen deprivation. Therefore, a combination of an angiogenesis inhibitor with agents blocking c-Met and the downstream regulation pathway as a multitarget therapy would have greater therapeutic efficacy $(9,14,19)$. However, before such potential clinical tools can be developed, it is necessary to establish that at the time of diagnosis, tumour cells exhibit increased vasculature associated with c-Met dysregulation, in parallel with tumour aggressiveness and poor patient outcome.

In the present study, we have compared expression of c-Met and signal transducers in a large series of breast carcinomas from patients categorised as deceased or alive with and without metastases, in correlation with CD146 expression, as a marker of endothelial cell activation and tumour angiogenesis, in subgroups of patients classified according to clinical outcome and nodal status.

\section{Materials and methods}

Breast tumour samples and patients' data. Breast carcinoma samples were obtained from 930 patients who had undergone initial surgery in the Hôpital de la Conception (PB). Tissue fragments were selected from our archival tumour paraffin blocks. All tumour samples used for TMA construction were fixed in buffered formalin, paraffin-embedded at controlled temperature and stored at $18-22^{\circ} \mathrm{C}$. Patient follow-up ranged from 4-10 years (median, 6.5 years). All patients were informed at the time of operation that tissue blocks stored in the laboratory archives might be used for delayed diagnostic and research purposes, and gave their agreement.

\section{Methods}

Tissue microarray (TMA) construction. TMA were constructed as previously described (20-23). Briefly, for each tumour, two representative tumour areas were delineated by circling within tissue sections ( $\mathrm{SG}, \mathrm{CC}, \mathrm{JD}, \mathrm{SCM}$ ) appropriate areas with a permanent black pen on hematoxylin and eosinstained paraffin sections in order to guide the technicians' punches of cores from the primary paraffin block. Cores were sampled using an ALPHELYS arraying device (78370 Plaisir, France). Core cylinders of 0.6-mm diameter punched from the donor block were then deposited in the recipient paraffin block. TMA sections (4- $\mu \mathrm{m}$ thick) were cut $24 \mathrm{~h}$ before immunohistochemical processing.

A total of six TMA blocks were constructed enclosing altogether 1860 cores, corresponding to 2 cores per individual tumour and 930 patients. 
Table I. Antibody sources for immunohistochemical tests.

\begin{tabular}{lccc}
\hline Antibodies & Origin & $\begin{array}{c}\text { Immunostaining } \\
\text { location }\end{array}$ & Clone/type \\
\hline
\end{tabular}

$\begin{array}{llll}\begin{array}{lll}\text { Tumour spreading/ } \\ \text { signalling } \\ \text { c-Met }\end{array} & \text { Novacastra, Tebu, France } & 1: 20 & \\ \text { FAK } & \text { Cell signalling, Ozyme, France } & 1: 30 & \text { Cytoplasm } \\ \text { PI3K } & \text { Cell signalling, Ozyme, France } & 1: 20 & \text { Cytoplasm } \\ \text { JAK } & \text { Cell signalling, Ozyme, France } & 1: 100 & \text { Cytoplasm }\end{array}$

8F11 mouse monoclonal

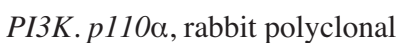
JAK 1 Tyr 1022-1023 rabbit polyclonal

Angiogenesis/

signalling

CD146

Novocastra, Tebu, France

Automated immunohistochemical procedure. The immunohistochemical procedure was performed with a Ventana Benchmark autostainer as previously reported (24-28) using the specific antibodies listed in Table I.

Slides were incubated for $32 \mathrm{~min}$ at $37^{\circ} \mathrm{C}$ with specific primary antibodies. Diaminobenzidin or 3-amino-9-ethylcarbazol were used as chromogens and slides were counterstained with hematoxylin before mounting. Positive and negative controls were assessed using external usual full section and deletion of primary antibodies, respectively.

Preliminary validation of immunodetection and TMA comparison of c-Met immunoexpression in paraffin and frozen sections. c-Met immunoexpression on 120 paraffin sections was compared to that on 120 frozen sections from tissue blocks sampled in the same tumours. In this preliminary study, we observed that c-Met expression in frozen breast carcinoma samples correlated with poor survival (unpublished data). Comparison of semiquantitatively evaluated c-Met immunostaining showed similar results to immunostained paraffin sections after antigen retrieval with the Ventana Benchmark device, and also revealed a significant correlation of immunostaining patterns in both substrates (Spearman's correlation coefficient $\mathrm{r}=0.694, \mathrm{p}<0.01)$.

Comparison of c-Met expression in different cores punched from the same tumour. Evaluation of c-Met immunoexpression in 50 breast carcinoma cases selected for TMA showed similar immunostaining in multiple cores sampled from different areas (but of similar cellularity) of the donor blocks (Spearman's correlation coefficient $\mathrm{r}=0.784, \mathrm{p}<0.01$ ). This result indicates that a limited number of cores (two in the present study) was sufficient when areas in the donor blocks were properly delineated and representative of the tumour.

Comparison of semiquantitative and quantitative analysis using image analysis. Semiquantitative evaluation was first used to classify the immunoexpression as negative or positive. The positive cores were further categorised as: weak (1+), intermediate $(2+)$, or intense $(3+)$ staining, based on the intensity and extent of immunoreaction. This evaluation significantly correlated with the densitometric quantification of immunoreactivity assessed by SAMBA image analysis, when both methods were applied on 120 cores and compared for one antibody (Spearman's correlation coefficient $r=0.728$, $\mathrm{p}<0.01)$.

Image analysis procedure. The TMA analysis with the SAMBA 2050 automated device (SAMBA Technologie, Meylan/Grenoble, France) (26-28) was performed according to the following protocol.

First, an image of the entire slide was built up using a low-power magnification ( $\mathrm{x} 2$, pixel dimension $3.7 \mu \mathrm{m})$. This image was made of a mosaic of images acquired along a rectangular grid with contiguous fields. Second, the area of the slide containing the TMA cores was automatically delineated and scanned at higher magnification (x10, pixel dimension $7.4 \mu \mathrm{m}$ ). Third, after autofocusing, the images were acquired with an overlap greater than the largest mechanical positioning error. Using the image contents, a matching algorithm determined precisely the relative position of each image with respect to its neighbours. Calculated overlap was removed from images to produce a new set of higher magnification (x10) images, thus covering precisely the cores of interest. A specially developed tool referred to as TMA crop then allowed superimposition of the TMA grid onto the reduced image and precise alignment of each node of the grid with the core location within the image. The final step was performed automatically using the core image contents to ensure pixel precision of the match. From the images acquired with $\mathrm{x} 20$ magnification, a new set of images was next computed, one for each core. After colour analysis of the core images, the SAMBA 'immuno' software was applied as previously reported (15-17,25-28) in usual full tissue sections. Several parameters per core were computed: the area of counterstaining, the ratio of the positive area versus counterstained areas and a quick score (percentage of positive area $\mathrm{x}$ mean optical density). Optical density (OD) was evaluated on a scale of grey levels (arbitrary units) ranging from $0(100 \%$ transmission, OD $=0)$ to $255(1 \%$ transmission, $\mathrm{OD}=2$ ). The computation of each parameter 
A

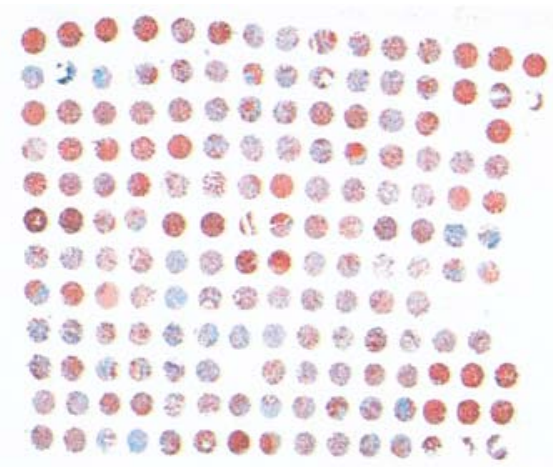

B

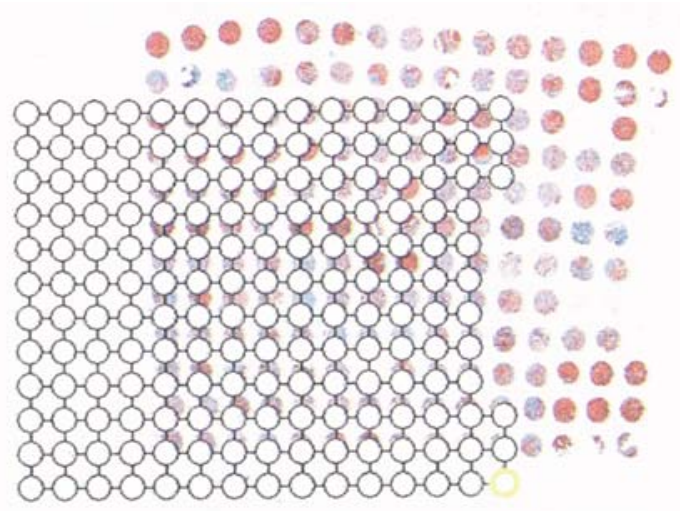

C

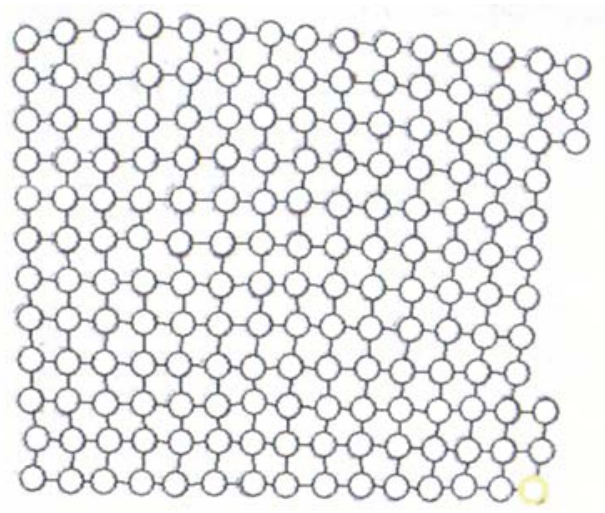

D

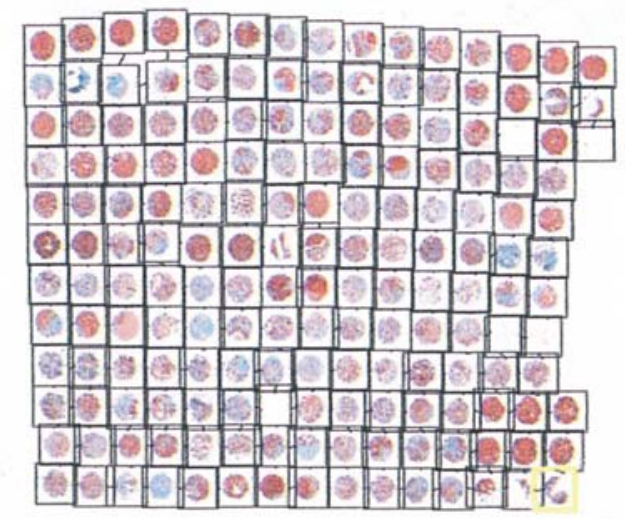

Figure 1. Steps of SAMBA software processing before densitometry on TMA. (A) Reference grid, (B and C) precrop of digitized TMA and superimposed grid, (D) cropped final image before image analysis (densitometry).

obtained provided numerical values consisting of continuous variables for statistical tests.

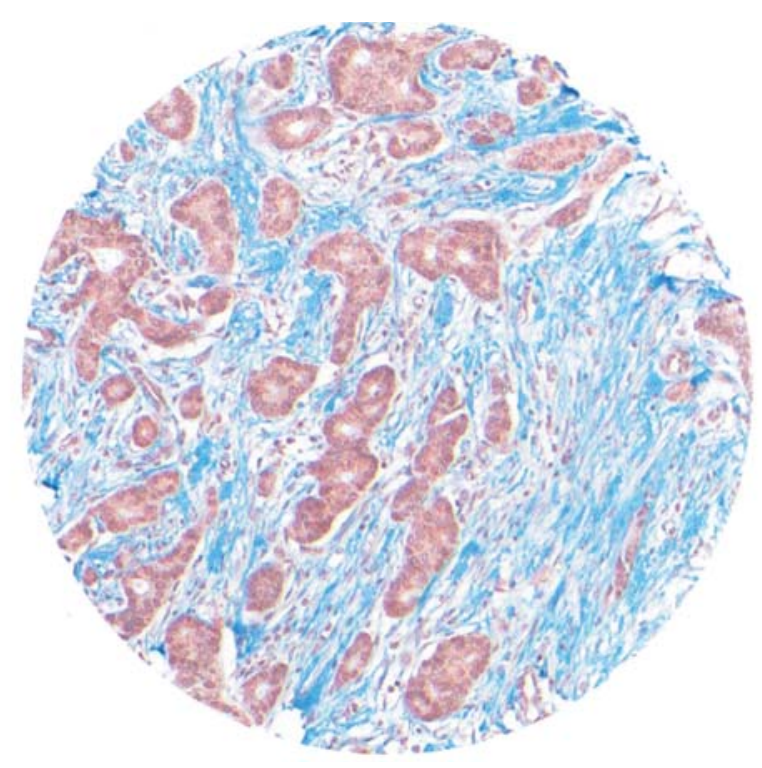

Figure 2. High magnification of one core $(0.6 \mathrm{~mm}$ in diameter) from an individual breast cancer tumour included in TMA: immunostaining with anti-c-Met, Ventana Benchmark autostainer and kit.

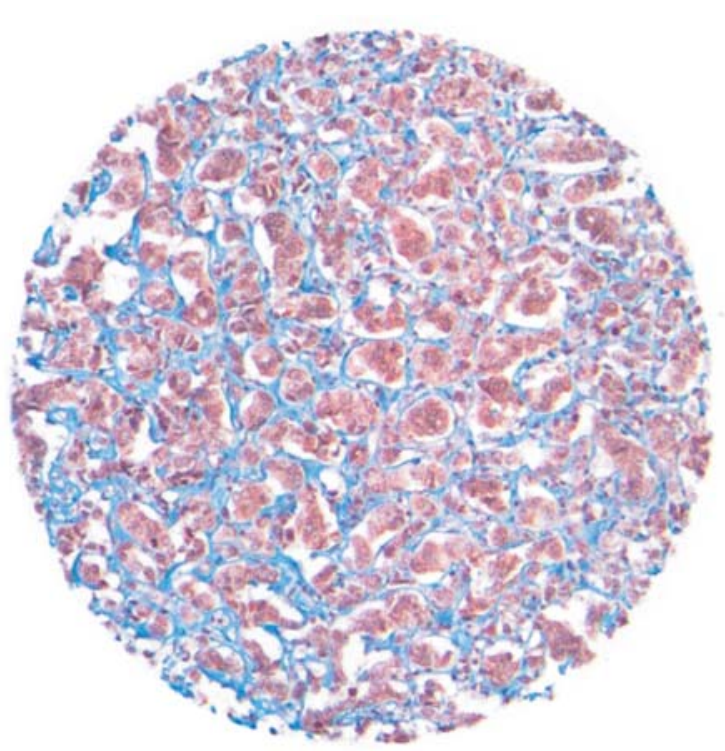

Figure 3. High magnification of one core $(0.6 \mathrm{~mm}$ in diameter) from an individual breast cancer tumour included in TMA: immunostaining with anti-PI3K, Ventana Benchmark autostainer and kit.

For the present study, the immunostained 60 TMA and 18,600 immunostained core sections resulting from the 6 different TMA and 10 antibodies were run according to this procedure.

Statistical analysis. Statistical analyses were performed using NCSS 2005 (25-28) and Statistica 2006 statistical softwares. The concordance between the immunoexpression of markers: i) in frozen and fixed tissues; ii) in full section and TMA sections; and iii) by semiquantitative and automated analysis, were examined using Spearman's e rank correlation. Comparison of mean parameters for each marker was assessed by non-parametric tests. Mean values were computed from 


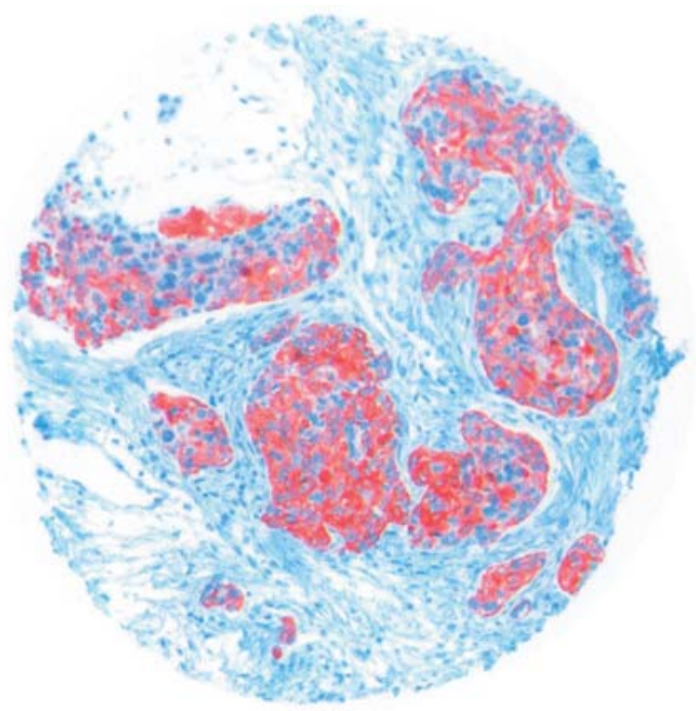

Figure 4. High magnification of one core $(0.6 \mathrm{~mm}$ in diameter $)$ from an individual breast cancer tumour included in TMA: immunostaining with anti-FAK, Ventana Benchmark autostainer and kit.

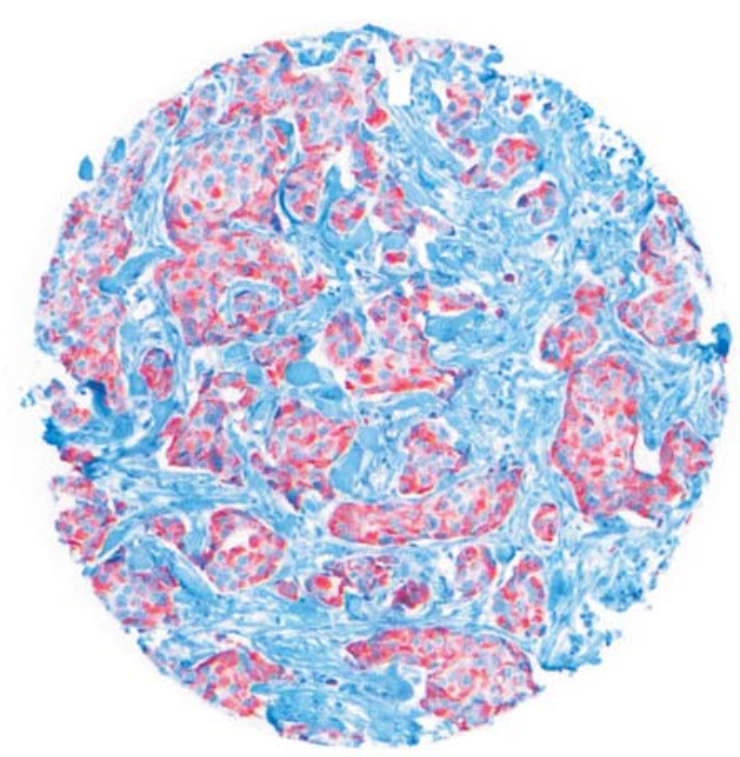

Figure 5. High magnification of one core $(0.6 \mathrm{~mm}$ in diameter) from an individual breast cancer tumour included in TMA: immunostaining with anti-JAK, Ventana Benchmark autostainer and kit.

measurements in the 2 cores from each tumour, before correlation. Contingency table analysis was used to analyse the relationship between protein expression in TMA of tumour sets. All p-values were two-sided. For each antibody, univariate analysis was conducted using Mann-Whitney and/or Kolgomorov, and $\chi^{2}$ tests. Only one parameter of immunostaining (percentage of positive surface) was retained in order to limit the amount of data and to facilitate the statistical analysis in the present initial part of our study design.

Procedures for the quantification and cropping stage are shown in Fig. 1 and the distribution of immunolabelling within sections of tumour cores with the various antibodies are shown in Figs. 2-7.

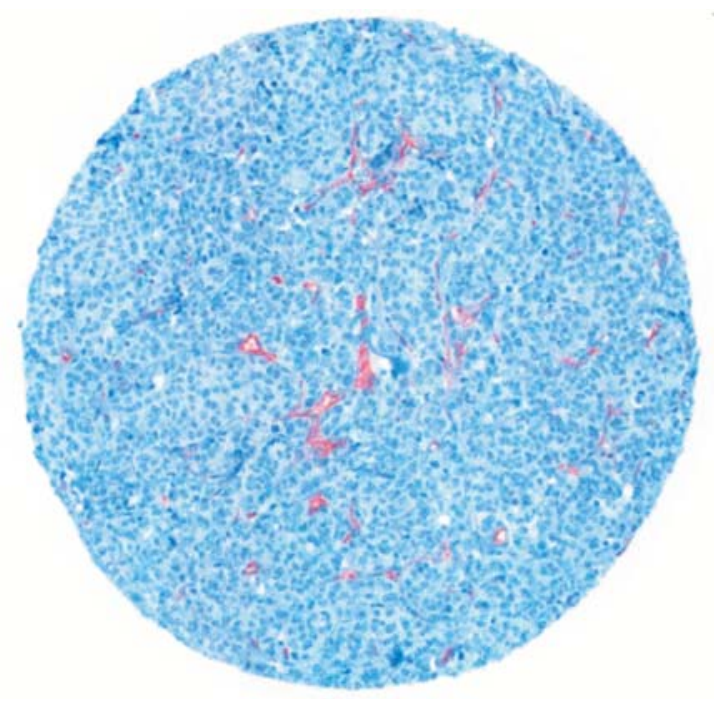

Figure 6. High magnification of one core $(0.6 \mathrm{~mm}$ in diameter $)$ from an individual breast cancer tumour included in TMA: immunostaining with anti-CD146, Ventana Benchmark autostainer and kit.

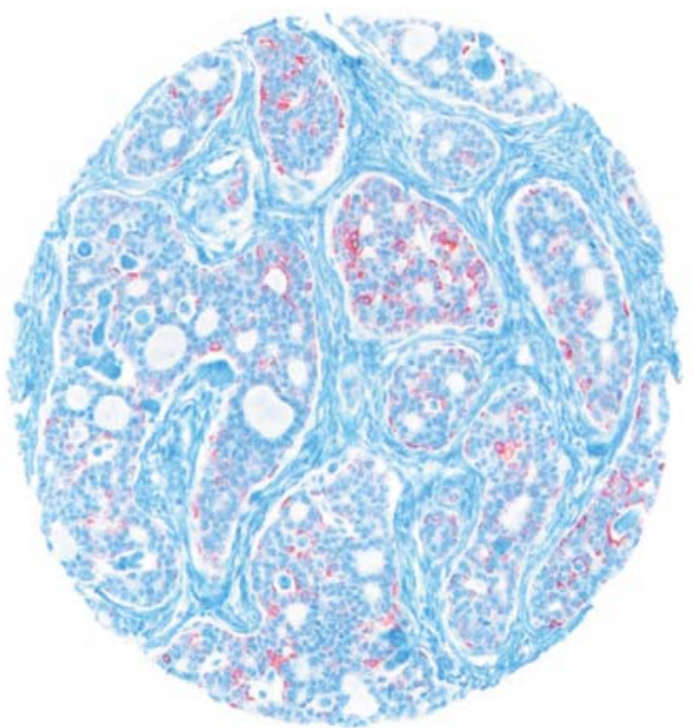

Figure 7. High magnification of one core $(0.6 \mathrm{~mm}$ in diameter $)$ from an individual breast cancer tumour included in TMA: immunostaining with anti-FYN, Ventana Benchmark autostainer and kit.

\section{Results}

c-Met overexpression in tumours with unfavorable outcome (tumour spreading). Immunostaining with anti-c-Met produced higher levels of cytoplasmic labelling (Fig. 2) in tumours from deceased or metastatic patients (Table II), in terms of both ratio of positive to negative cases $(\mathrm{p}=0.01)$ and greater $\mathrm{c}-\mathrm{Met}-$ positive surface $(\mathrm{p}<0.0001)$, particularly in node-negative patients $(\mathrm{p}<0.0001)$ (Table II). Similarly, PI3K expression (Fig. 3) was greater in tumours of poor prognosis $(p<0.0001)$, in terms of positive/negative cases and extent of positive staining (Table II). Results were similar for FAK expression (Fig. 4) ( $p=0.0157$ and $p<0.0001$ for positive/negative cases and for extent of staining, respectively) (Table II). However, 
Table II. Quantitative distribution of c-Met, PI3K, FAK and JAK immunostaining in TMA, evaluated by SAMBA device.

\begin{tabular}{|c|c|c|c|c|c|c|c|c|}
\hline & \multicolumn{5}{|c|}{$\begin{array}{l}\text { Number of positive versus negative } \\
\text { cases }\left(\chi^{2} \text { square test }\right)\end{array}$} & \multicolumn{3}{|c|}{$\begin{array}{l}\text { Mean percentage of stained } \\
\text { surface (Mann-Whitney test) }\end{array}$} \\
\hline & \multicolumn{2}{|c|}{ Deceased/metastasis } & & \multicolumn{2}{|c|}{ Alive/no metastasis } & \multirow{2}{*}{$\begin{array}{l}\text { Deceased/ } \\
\text { metastasis }\end{array}$} & \multirow{2}{*}{\multicolumn{2}{|c|}{$\begin{array}{c}\text { Alive/ } \\
\text { no metastasis }\end{array}$}} \\
\hline & Positive & Negative & & Positive & Negative & & & \\
\hline \multicolumn{9}{|l|}{ c-Met } \\
\hline $\begin{array}{l}\text { All patients } \\
(\mathrm{n}=916)\end{array}$ & $270 / 283$ & $13 / 283$ & $\mathrm{p}<0.01$ & $50 / 633$ & $583 / 633$ & $\begin{array}{l}0.455 \\
\mathrm{r}=0-13.89 \\
\mathrm{SD}=1.19\end{array}$ & $\mathrm{p}<0.0001$ & $\begin{array}{l}0.313 \\
\mathrm{r}=0-9.55 \\
\mathrm{SD}=0.91\end{array}$ \\
\hline $\begin{array}{l}\text { Node-negative patients } \\
(n=477)\end{array}$ & $73 / 75$ & $2 / 75$ & $\mathrm{p}<0.00001$ & $2 / 402$ & $400 / 402$ & $\begin{array}{l}0.645 \\
r=0-13 \\
S D=1.45\end{array}$ & $\mathrm{p}<0.0001$ & $\begin{array}{l}0.35 \\
\mathrm{r}=0-9.55 \\
\mathrm{SD}=1.23\end{array}$ \\
\hline $\begin{array}{l}\text { Node-positive patients } \\
(n=439)\end{array}$ & & & $\mathrm{p}=0.1614$ & & & $\begin{array}{l}0.409 \\
\mathrm{r}=0-13.89 \\
\mathrm{SD}=1.24\end{array}$ & $\mathrm{p}<0.0001$ & $\begin{array}{l}0.213 \\
\mathrm{r}=0-3.06 \\
\mathrm{SD}=0.48\end{array}$ \\
\hline \multicolumn{9}{|l|}{ PI3K } \\
\hline $\begin{array}{l}\text { All patients } \\
(\mathrm{n}=928)\end{array}$ & $245 / 283$ & $39 / 283$ & $\mathrm{p}<0.00001$ & $163 / 645$ & $482 / 645$ & $\begin{array}{l}36.568 \\
r=0-97.72 \\
S D=15.72\end{array}$ & $\mathrm{p}<0.0001$ & $\begin{array}{l}8.515 \\
r=0-99.65 \\
S D=28.68\end{array}$ \\
\hline $\begin{array}{l}\text { Node-negative patients } \\
(n=477)\end{array}$ & $75 / 75$ & $0 / 75$ & $\mathrm{p}<0.00001$ & $0 / 402$ & $402 / 402$ & $\begin{array}{l}21.692 \\
r=0-68.13 \\
S D=9.47\end{array}$ & $\mathrm{p}<0.0001$ & $\begin{array}{l}0.0129 \\
\mathrm{r}=0-2.25 \\
\mathrm{SD}=0.019\end{array}$ \\
\hline $\begin{array}{l}\text { Node-positive patients } \\
(\mathrm{n}=451)\end{array}$ & & & $\mathrm{p}>0.05$ & & & $\begin{array}{l}43.826 \\
r=0-91.97 \\
S D=24.78\end{array}$ & $\mathrm{p}<0.0001$ & $\begin{array}{l}23.653 \\
\mathrm{r}=0-97.72 \\
\mathrm{SD}=18.62\end{array}$ \\
\hline \multicolumn{9}{|l|}{ FAK } \\
\hline $\begin{array}{l}\text { All patients } \\
(\mathrm{n}=925)\end{array}$ & $217 / 287$ & $70 / 287$ & $\mathrm{p}=0.0157$ & $183 / 638$ & $455 / 638$ & $\begin{array}{l}0.308 \\
\mathrm{r}=0-11.63 \\
\mathrm{SD}=0.82\end{array}$ & $\mathrm{p}<0.0001$ & $\begin{array}{l}0.199 \\
r=0-27.99 \\
S D=1.55\end{array}$ \\
\hline $\begin{array}{l}\text { Node-negative patients } \\
(\mathrm{n}=477)\end{array}$ & & & $\mathrm{p}>0.05$ & & & $\begin{array}{l}0.190 \\
r=0-11.63 \\
S D=0.84\end{array}$ & $\mathrm{p}<0.001$ & $\begin{array}{l}0.0352 \\
\mathrm{r}=0-1.24 \\
\mathrm{SD}=0.14\end{array}$ \\
\hline $\begin{array}{l}\text { Node-positive patients } \\
(\mathrm{n}=446)\end{array}$ & & & $\mathrm{p}>0.05$ & & & $\begin{array}{l}0.384 \\
\mathrm{r}=0-5.54 \\
\mathrm{SD}=0.80\end{array}$ & $\mathrm{p}<0.001$ & $\begin{array}{l}0.250 \\
\mathrm{r}=0-9.77 \\
\mathrm{SD}=0.88\end{array}$ \\
\hline \multicolumn{9}{|l|}{ JAK } \\
\hline $\begin{array}{l}\text { All patients } \\
(\mathrm{n}=918)\end{array}$ & $140 / 283$ & $143 / 283$ & $\mathrm{p}<0.01$ & $494 / 635$ & $141 / 635$ & $\begin{array}{l}0.461 \\
r=0-8.50 \\
S D=0.59\end{array}$ & $\mathrm{p}<0.01$ & $\begin{array}{l}0.157 \\
\mathrm{r}=0-16.01 \\
\mathrm{SD}=2.01\end{array}$ \\
\hline $\begin{array}{l}\text { Node-negative patients } \\
(n=477)\end{array}$ & $70 / 75$ & $5 / 75$ & $\mathrm{p}<0.0001$ & $141 / 402$ & $494 / 402$ & $\begin{array}{l}0.184 \\
r=0-8.50 \\
S D=0.68\end{array}$ & $\mathrm{p}<0.01$ & $\begin{array}{l}0.179 \\
\mathrm{r}=0-11.28 \\
\mathrm{SD}=1.20\end{array}$ \\
\hline $\begin{array}{l}\text { Node-positive patients } \\
(\mathrm{n}=441)\end{array}$ & & & $\mathrm{p}>0.5$ & & & & $\mathrm{p}>0.5$ & \\
\hline
\end{tabular}

Variations in numbers of patients among the 930 included in the series, result from core section losses in TMA during technical procedure. 
Table III. Quantitative distribution of CD146 and FYN immunostaining in TMA, evaluated by SAMBA device.

\begin{tabular}{|c|c|c|c|c|c|c|c|c|}
\hline & \multicolumn{5}{|c|}{$\begin{array}{l}\text { Number of positive versus negative } \\
\left.\text { cases ( } \chi^{2} \text { square test }\right)\end{array}$} & \multicolumn{3}{|c|}{$\begin{array}{l}\text { Mean percentage of stained } \\
\text { surface (Mann-Whitney test) }\end{array}$} \\
\hline & \multicolumn{2}{|c|}{ Deceased } & & \multicolumn{2}{|c|}{ Alive } & \multirow[t]{2}{*}{ Deceased } & \multirow{2}{*}{\multicolumn{2}{|c|}{ Alive }} \\
\hline & Positive & Negative & & Positive & Negative & & & \\
\hline \multicolumn{9}{|l|}{ CD146 } \\
\hline $\begin{array}{l}\text { All patients } \\
(\mathrm{n}=920)\end{array}$ & $193 / 285$ & $92 / 285$ & $\mathrm{p}=0.0105$ & $184 / 635$ & $454 / 635$ & $\begin{array}{l}\mathrm{m}=0.269 \\
\mathrm{r}=0-37.58 \\
\mathrm{SD}=2.17\end{array}$ & $\mathrm{p}=0.025$ & $\begin{array}{l}0.081 \\
\mathrm{r}=0-11.23 \\
\mathrm{SD}=0.38\end{array}$ \\
\hline $\begin{array}{l}\text { Node-negative patients } \\
(\mathrm{n}=478)\end{array}$ & & & $\mathrm{p}>0.05$ & & & & $\mathrm{p}>0.05$ & \\
\hline $\begin{array}{l}\text { Node-positive patients } \\
(\mathrm{n}=432)\end{array}$ & $87 / 110$ & $23 / 110$ & $\mathrm{p}=0.0063$ & $51 / 322$ & $271 / 322$ & $\begin{array}{l}\mathrm{m}=0.373 \\
\mathrm{r}=0-37.58 \\
\mathrm{SD}=3.14\end{array}$ & $\mathrm{p}<0.001$ & $\begin{array}{l}\mathrm{m}=0.090 \\
\mathrm{r}=0-2.83 \\
\mathrm{SD}=0.25\end{array}$ \\
\hline \multicolumn{9}{|l|}{ FYN } \\
\hline $\begin{array}{l}\text { All patients } \\
(\mathrm{n}=927)\end{array}$ & $205 / 289$ & $84 / 289$ & $\mathrm{p}=0.0209$ & $428 / 638$ & $210 / 638$ & $\begin{array}{l}\mathrm{m}=0.085 \\
\mathrm{r}=0-3.03 \\
\mathrm{SD}=0.30\end{array}$ & $\mathrm{p}<0.001$ & $\begin{array}{l}\mathrm{m}=0.073 \\
\mathrm{r}=0-3.34 \\
\mathrm{SD}=0.22\end{array}$ \\
\hline $\begin{array}{l}\text { Node-negative patients } \\
(n=477)\end{array}$ & & & $\mathrm{p}>0.05$ & & & $\begin{array}{l}\mathrm{m}=0.070 \\
\mathrm{r}=0-3.34 \\
\mathrm{SD}=0.22\end{array}$ & $\mathrm{p}=0.00029$ & $\begin{array}{l}\mathrm{m}=0.031 \\
\mathrm{r}=0-1.03 \\
\mathrm{SD}=0.1\end{array}$ \\
\hline $\begin{array}{l}\text { Node-positive patients } \\
(\mathrm{n}=452)\end{array}$ & $97 / 114$ & $17 / 114$ & $\mathrm{p}<0.00001$ & $41 / 335$ & $294 / 335$ & $\begin{array}{l}\mathrm{m}=0.140 \\
\mathrm{r}=0-3.02 \\
\mathrm{SD}>0.38\end{array}$ & $\mathrm{p}=0.00096$ & $\begin{array}{l}\mathrm{m}=0.086 \\
\mathrm{r}=0-2.41 \\
\mathrm{SD}=0.24\end{array}$ \\
\hline
\end{tabular}

Variations in numbers of patients among the 930 included in the series, result from core section losses in TMA during technical procedure.

FAK expression retained prognostic significance in nodenegative patients only when the extent of surface stained was considered.

JAK (Fig. 5) was overexpressed in tumours with unfavorable outcome (Table II), suggesting that activation of c-Met signal transducers may also result from simultaneous activation of non-tyrosine kinase receptors.

Together, these data show that these molecules are overexpressed in malignant breast tumours with unfavorable outcome and suggest that they can be regarded as potential candidate targets for specific therapy.

CD146 overexpression in tumours with unfavorable outcome (tumour vasculature). CD146 was observed in tumours as a thin and well-delineated labelling of tumour endothelial cells of small vessels (Fig. 6) greater in metastatic or deceased patients, in terms of both the ratio of positive to negative cases and extent of immunostained surfaces, similarly to FYN expression (Fig. 7), reflecting CD146 activation (Table III).

\section{Discussion}

Poor prognosis and c-Met overexpression. In breast carcinomas, c-Met expression has been shown in several studies to correlate with tumour invasiveness, metastasis and shorter overall survival (29-32). Our results confirm these data in a significantly larger series $(n=930)$ using objective quantification through standardised image analysis and immunocytochemical procedures in TMA. The overexpression of c-Met, despite lack of mutations or amplification $(3-6,13)$ supports the hypothesis that specific therapy must target the protein itself and that immunohistochemical tests can be regarded as suitable for identifying protein targets in individual tumours. Antibodies against c-Met, small molecules such as PHA66752 and kerin that target c-Met, or the NK4 that blocks HGF binding to c-Met have been reported to act as specific c-Met inhibitors (33-35), while other tyrosine kinase inhibitors such as Iressa, Tarceva, Herceptin and Genifinib do not inhibit c-Met activity $(6,13)$.

No TMA study of signal transducers in human breast carcinomas has been previously reported, although some immunohistochemical studies using large sections have been reported $(33,34,36,37)$ The simultaneous expression of downstream transducers supports the hypothesis of overexpressed c-Met functionality in breast cancer, resulting in cell motility, dissociation, invasion and adhesion to extracellular matrix via pathways involving PI3K, FAK and ERK/ PAK-P21, and associated branching morphogenesis through 
STAT-3/JAK pathways. We observed that JAK was also overexpressed in tumours associated with unfavorable outcome, suggesting that c-Met activation of signal transducers probably occurs concomitantly with non-RTK family receptors, since JAK is activated by the cytokine IL- 6 transmembrane receptor. Small molecules have been reported to act directly against a pivotal kinase and also against Gab 1. In particular, PHA66572 blocks PI3K function in cell lines from small-cell and gastric carcinomas and from gliomas, whereas SU11274 inhibits FAK, which is responsible for loss of intracellular junctions and increased cell matrix adhesion during motility and scatter responses in cell culture (33-35). Therefore, the demonstrated functionality of c-Met acting through downstream transducers in signalling pathways provides a wider range of potential specific targets. This is the first report of such a broad data-set obtained using a simple means of molecule identification such as quantitative high-throughput immunocytochemistry with TMA methodology, that may also be suitable for use with individual tumours at the diagnostic stage, since it requires only small amounts of tissue, and is standardisable and cost-effective.

Relevance of co-inhibition of c-Met and angiogenesis activators. HGF and c-Met are implicated in tumour angiogenesis and participate in the regulation of growth invasion and mobility in vascular endothelial cells, as well as formation of three dimensional endothelial capillary tubes in vitro (3-6) and neovascularisation in tumour graft $(13,14)$. HGF has also been demonstrated to regulate the expression of proangiogenic factors including VEGF and angiogenic response by endothelial cells such as VEGF-R2.

Angiogenesis, like vascular homeostasis, is linked to the functional state of interendothelial junctions which are modulated by growth and activation of endothelial cells. Molecules located in adherens junctions (e.g., VE-cadherin) or occluding and tight junctions (e.g., CD146/Mel-CAM, CD105/endoglin, CD34/PE-CAM) are crucial to angiogenesis. CD146 is a transmembrane protein belonging to the immunoglobulin superfamily, the ligand of which remains unknown. It is a structural component of interendothelial junctions, present on endothelial cells regardless of the site or size of the vessels, although it was initially reported as a progression marker in melanomas. Melanocytic tumour cells express CD146 (Melanoma Cell Adhesion Molecule; MelCAM) along with endothelial cells, trophoblastic cells, activated and tumourous $\mathrm{T}$ lymphocytes, but other human malignant tumours do not $(38,39)$. This is consistent with our finding that CD146 antibody reacted only with endothelial cells but not with carcinomatous cells.

While the extracellular domain of CD146 is involved in endothelial-endothelial cell adhesion through tight junctions, the intracellular domain promotes the recruitment of the SCR family kinase FYN as well as tyrosine phosphorylation of several intracellular proteins including FAK (and paxillin) that are present in focal adhesion plaques (reviewed in ref. in 38). In our study, increased FAK immunostaining in breast carcinomas of poor outcome probably results from increased c-Met and CD146 cellular signals which both also act upon angiogenesis and actin skeleton rearrangement. Experimental studies have shown that anti-CD146 monoclonal antibodies induce inhibition of proliferation and migration of endothelial cells and of angiogenesis reflected by a reduction in blood vessel density, associated with tumour growth inhibition $(38,39)$. In particular, treatment with AA98 monoclonal anti-CD146 of human xenographed tumour models using subcutaneously injected malignant cells (leiomyosarcoma, pancreatic and hepatocellular carcinomas) induced significant tumour reduction with no metastasis. This treatment produced non-cytotoxic effects in animals and its efficacy increased when AA98 was combined with other anticancer agents (39).

However, despite the fact that CD146 could constitute a target for cancer therapy as well as being an excellent marker of tumour vasculature through its expression in activated endothelial cells, no study has yet shown anti-CD146 therapy to be efficient in patients with carcinomas. Our data suggest that inhibition of CD146 and c-Met in tumours overexpressing both markers should have a synergistic effect in potentially reducing angiogenesis and cell spreading, but clinical studies are required to demonstrate the efficacy of this strategy for human therapy.

Hypoxia promotes tumour growth by transcriptional activity of the $c$-met proto-oncogene through a complementary pathway that is independent of the angiogenic response and mediated by upregulated VEGF through the HIF and CA IX pathway (40). This observation raised the possibility that antiangiogenic therapy, by reducing vascularisation in a primary tumour, promotes the spread of cancer cells towards a more highly oxygenated environment or distant tissue, thus favoring metastasis. It also provides support for the proposal $(19,40)$ that a combination of selective angiogenic inhibitors with c-Met or HGF inhibitors should significantly reduce tumour progression. Also, in experimental studies, noninvasive assessment of tumour angiogenesis is possible using magnetic resonance imaging (MRI), computed tomography (CT) and positron emission tomography (PET), providing dynamic images of microvasculature that can be used in assessing inhibition of angiogenesis. Some initial study of angiogenesis inhibitors has demonstrated changes in vascular permeability and in volume fraction of metabolism after therapy which may be predictive of clinical efficiency of this therapy, in correlation with tumour regression (19). This procedure may be of value for patient management.

In conclusion, we used TMA from a series of 930 patients with breast carcinoma and developed a standardised highthroughput method for quantifying immunoprecipitates on core sections, different from that previously described $(41,42)$ and poorly documented in the literature as a suitable tool to evaluate proteomic immunohistochemical expression of tumour cells in major human tumours. Our results show that overexpression of c-Met, as well as of PI3K and FAK, signal tranducers reflecting c-Met functionality and acting on tumour cell spreading, correlates with poor survival. CD146 labelling of activated endothelial cells, that are implicated in neoangiogenesis and the subsequent metastatic process through blood vessels, also show overexpression in breast cancers with poor outcome. These observations suggest that standardised immunodetection procedures applied to individual carcinomas at the time of diagnosis, could not only yield significant prognostic data but also provide a basis for a potential specific therapy strategy combining inhibitors of c-Met and angiogenesis with cytotoxic chemotherapy and/or radiotherapy. 


\section{Acknowledgements}

This study was supported by the French Ministry of Health and Research (Canceropole 2004-2006).

\section{References}

1. Bladt F, Riethmacher D, Isenmann S, Aguzzi A and Birchmeier C: Essential role for the c-Met receptor in the migration of myogenic precursor cells into the limb bud. Nature 376: 768-771, 1995.

2. Schmidt C, Bladt S, Goedecke S, Goedecke S, Brinkmann V, Zschiesche W, Sharpe M, Gherardi E and Birchmeier C: Scatter factor/hepatocyte growth factor is essential for liver development. Nature 373: 699-702, 1995.

3. Birchmeier C, Birchmeier W, Gherardi E and Vande Woude GF: Met, metastasis, motility and more. Nat Rev Mol Cell Biol 4: 915-925, 2003.

4. Ma PC, Maulik G, Christensen J and Salgia R: C-Met structure, functions and potential for therapeutic inhibition. Cancer Metastasis Rev 22: 309-325, 2003.

5. Trusolino L and Comoglio PM: Scatter-factor and semaphoring receptors: cell signaling for invasive growth. Nat Rev Cancer 2: 289-300, 2002.

6. Maulik G, Shrikhande A, Kijima T, Ma PC, Morrison PT and Saldia R: Role of the hepatocyte growth factor receptor, c-Met in oncogenesis and potential for therapeutic inhibition. Cytokine Growth Factor Rev 13: 41-59, 2002.

7. Moghul A, Lin L, Beedle A, Kanbour-Shakir A, De Frances MC, Liu Y and Zarnegar R: Modulation of c-Met proto-oncogene (HGF receptor) mRNA abundance by cytokines and hormones: evidence for rapid decay of the $8 \mathrm{~kb}$ c-Met transcript. Oncogene 9: 2045-2052, 1994.

8. Furge KA, Kiewlich D, Le P, Vo MN, Faure M, Howlett AR, Lipson KE, Woude GF and Webb CP: Suppression of Rasmediated tumourigenicity and metastasis through inhibition of the Met receptor tyrosine kinase. Proc Natl Acad Sci USA 98: 10722-10727, 2001.

9. Pennacchietti S, Michieli P, Galluzzo M, Mazzone M, Giordano S and Comoglio PM: Hypoxia promotes invasive growth by transcriptional activation of the met protooncogene. Cancer Cell 3: 347-361, 2003

10. Di Renzo MF, Olivero M, Giacomini A, Porte H, Chastre E, Mirossay L, Nordlinger B, Bretti S, Bottardi S, Giordano S, et al: Overexpression and amplification of the met/HGF receptor gene during the progression of colorectal cancer. Clin Cancer Res 1: 147-154, 1995 .

11. Hara T, Ooi A, Kobayashi M, Mai M, Yanagihara K and Nakanishi I: Amplification of c-myc, and c-met in gastric cancers: detection by fluorescence in situ hybridization. Lab Invest 78: 1143-1153, 1998

12. Wullich B, Sattler HP, Fischer U and Meese E: Two independent amplification events on chromosome 7 in glioma: amplification of the epidermal growth factor receptor gene and amplification of the oncogene Met. Anticancer Res 14: 577-579, 1994.

13. Christensen JG, Burrows J and Salgia R: C-met as a target for human cancer and characterization of inhibitors for therapeutic intervention. Cancer Lett 225: 1-26, 2005.

14. Christensen JG, Schreck R, Burrows J, Kuruganti P, Chan E, Le P, Chen J, Wang X, Ruslim L, Blake R, Lipson KE, Rampal J, Do S, Cui JJ, Cherrington JM and Mendel DB: A selective small molecule inhibitor of c-met kinase inhibits c-met-dependent phenotypes in vitro and exhibits cytoreductive antitumour activity in vivo. Cancer Res 63: 7345-7355, 2003.

15. Dalès JP, Garcia S, Meunier-Carpentier S, Andrac-Meyer L, Haddad O, Lavaut MN, Allasia C, Bonnier P and Charpin C: Overexpression of hypoxia-inducible factor HIF-1 $\alpha$ predicts early relapse in breast cancer: retrospective study in a series of 745 patients. Int J Cancer 116: 734-739, 2005.

16. Dalès JP, Garcia S, Carpentier S, Andrac L, Ramuz O, Lavaut MN, Allasia C, Bonnier P and Charpin C: Long-term prognostic significance of neoangiogenesis in breast carcinomas: comparison of Tie-2/Tek, CD105 and CD31 immunocytochemical expression. Hum Pathol 35: 176-183, 2004.

17. Charpin C, Garcia S, Bouvier C, Martini F, Andrac L, Bonnier P, Lavaut MN and Allasia C: CD31/PECAM automated and quantitative immunocytochemical assays in breast carcinomas: correlation with patient follow-up. Am J Clin Pathol 107: 534-541, 1997.
18. Charpin C, Dalès JP, Garcia S, Carpentier S, Djemli A, Andrac L, Lavaut MN, Allasia and Bonnier P: Tumor neoangiogenesis by CD31 and CD105 expression evaluation in breast carcinoma tissue microarrays. Clin Cancer Res 10: 5815-5819, 2004.

19. Gasparini G, Longo R, Fanelli M and Teicher BA: Combination of antiangiogenic therapy with other anticancer therapies: results, challenges and open question. J Clin Oncol 23: 1295-1311, 2005.

20. Kallioniemi OP, Wagner U, Kononen J and Sauter G: Tissue microarray technology for high-throughput molecular profiling of cancer. Hum Mol Genet 10: 657-662, 2001.

21. Torhorst J, Bucher C, Kononen J, Haas P, Zuber M, Kochli OR, Mross F, Dieterich H, Moch H, Mihatsch M, Kallioniemi OP and Sauter G: Tissue microarrays for rapid linking of molecular changes to clinical endpoints. Am J Pathol 159: 2249-2256, 2001 .

22. Ginestier C, Charafe-Jauffret E, Bertucci F, Eisinger F, Geneix J, Bechlian D, Conte N, Adelaide J, Toiron Y, Nguyen C, Viens P, Mozziconacci MJ, Houlgatte R, Birnbaum D and Jacquemier J: Distinct and complementary information provided by use of tissue and DNA microarrays in the study of breast tumour markers. Am J Pathol 161: 1223-1233, 2002.

23. Jacquemier J, Ginestier C, Rougemont J, Bardou VJ, Charafe-Jauffret E, Geneix J, Adelaide J, Koki A, Houvenaeghel G, Hassoun J, Maraninchi D, Viens P, Birnbaum D and Bertucci F: Protein expression profiling identifies subclasses of breast cancer and predicts prognosis. Cancer Res 65: 767-769, 2005.

24. Charpin C, Garcia S, Bonnier P, Martini F, Andrac L, Choux R, Lavaut MN and Allasia C: Reduced E-cadherin immunohistochemical expression in node-negative breast carcinomas correlates with 10-year survival. Am J Clin Pathol 9: 431-438, 1998.

25. Charpin C, Garcia S, Bonnier P, Martini F, Andrac L, Horschowski N, Lavaut MN and Allasia C: Prognostic significance (10 year follow up) of Nm23/NDPK automated and quantitative immunocytochemical assays in breast carcinomas. J Pathol 184: 401-407, 1998.

26. Charpin C, Garcia S, Bonnier P, Martini F, Andrac L, Horschowski N, Lavaut MN and Allasia C: Bcl-2 automated and quantitative immunocytochemical assays in breast carcinoma: correlation with 10-year follow-up. J Clin Oncol 16: 2025-2031, 1998.

27. Charpin C, Vielh P, Duffaud F, Devictor B, Andrac L, Lavaut MN, Allasia C, Horschowski N and Piana L: Quantitative immunocytochemical assays of P-glycoprotein in breast carcinomas: correlation to mRNA expression and to immunohistochemical prognostic indicators. J Natl Cancer Inst 20: 1539-1545, 1994.

28. Charpin C, Garcia S, Bouvier C, Devictor B, Andrac L, Choux R, Lavaut MN and Allasia C: Automated and quantitative immunocytochemical assays of CD44v6 in breast carcinomas. Hum Pathol 28: 289-296, 1997.

29. Tolgay Ocal I, Dolled-Filhart M, D'Aquila TG, Camp RL and Rimm DL: Tissue microarray based studies of patients with lymph node negative breast carcinoma show that met expression is associated with worse outcome but is not correlated with epidermal growth factor family receptors. Cancer 97: 1841-1848, 2003.

30. Camp RL, Rimm EB and Rimm DL: Met expression is associated with poor outcome in patients with axillary lymph node negative breast carcinoma. Cancer 86: 2259-2265, 1999.

31. Nakipoulou L, Gakiopoulou H, Keramopoulos A, Giannopoulou I, Athanassiadou P, Mavrommatis J and Davaris PS: C-met tyrosine kinase receptor expression is associated with abnormal betacatenin expression and unfavourable prognostic factors in invasive breast carcinoma. Histopathology 36: 313-325, 2000.

32. Lee WY, Chen HH, Chow NH, Su WC, Lin PW and Guo HR: Prognostic significance of co-expression of Ron and Met receptors in node-negative breast cancer patients. Clin Cancer Res 11: 2222-2228, 2005

33. Laird AD and Cherrington JM: Small molecule tyrosine kinase inhibitors: clinical development of anticancer agents. Expert Opin Investig Drugs 12: 51-64, 2003.

34. Matsumoto K and Nakamura T: NK4 (HGF-antagonist/angiogenesis inhibitor) in cancer biology and therapeutics. Cancer Sci 94: 321-327, 2003.

35. Wang X, Le P, Liang C, Chan J, Kiewlich D, Miller T, Harris D, Sun L, Rice A, Vasile S, Blake RA, Howlett AR, Patel N, McMahon G and Lipson KE: Potent and selective inhibitors of the Met [hepatocyte growth factor/scatter factor (HGF/SF) receptor] tyrosine kinase block HGF/SF-induced tumour cell growth and invasion. Mol Cancer Ther 2: 1085-1092, 2003. 
36. Schmitz KJ, Grabellus F, Callies R, Otterbach, Wohlschlaeger J, Levkau B, Kimmig KW and Baba HA: High expression of focal adhesion kinase (p125fak) in node-negative breast cancer is related to overexpression of HER-2/neu and activated Akt kinase but does not predict outcome. Breast Cancer Res 7: 194-203, 2005.

37. Lark AL, Livasy CA, Dressler L, Moore DT, Millikan RC, Geradts J, Iacocca M, Cowan D, Little D, Craven RJ and Cance W: High focal adhesion kinase expression in invasive breast carcinomas is associated with an aggressive phenotype. Mod Pathol 18: 1289-1294, 2005.

38. Anfosso F, Bardin N, Vivier E, Sabatier F, Sampol J and Dignat-George F: Outside-in signaling pathway linked to CD146 engagement in human endothelial cells. J Biol Chem 276: 1564-1569, 2001.
39. Yan X, Lin Y, Yang D, Shen Y, Yuan M, Zhang Z, Li P, Xia H, Li L, Luo D, Liu Q, Mann K and Bader BL: A novel anti-CD146 monoclonal antibody, AA98, inhibits angiogenesis and tumour growth. Immunobiology 102: 184-191, 2003.

40. Pouyssegur J, Dayan F and Mazure NM: Hypoxia signaling in cancer and approaches to enforce tumour regression. Nature 441: 437-443, 2006.

41. Camp RL, Chung GC and Rimm DL: Automated subcellular localization and quantification of protein expression in tissue microarrays. Nat Med 8: 1323-1327, 2002.

42. Pages F, Berger A, Camus M, Sanchez-Cabo F, Costes A, Molidor R, Mlecnik B, Kirilovsky A, Nilsson M, Damotte D, Meatchi T, Bruneval P, Cugnenc PH, Trajanoski Z, Fridman WH and Galon J: Effector memory T cells, early metastasis and survival in colorectal cancer. N Engl J Med 25: 2654-2666, 2006. 